\title{
Editorial
}

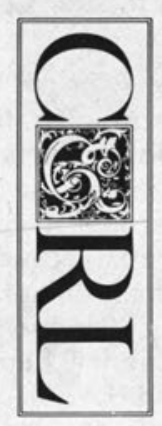

\section{New Programs, Existing Programs}

In an open letter to the California State University Board of Trustees, Scott Rice, a professor, complains, "Administrators, for all their obvious usefulness, have certain generic weaknesses. Administrators like to divert money to create new 'programs,' while not looking to the health of existing ones." This statement intrigued me when I first read it. So I earmarked it for further attention.

Later, Joseph Kramer, a science librarian here at CSU-Sacramento, routed the same letter to me and earmarked the same quote. "Charlie, pay close attention! This is a profoundly important statement."

Joe has sent several key articles to me over the years. A notable example is William Miller's much-discussed article "What's Wrong with Reference?" that appeared in American Libraries (May 1984). Joe and I often have different perspectives on the issues raised by these articles. But, we agree closely on the importance of the problems that they address.

The creation of new programs seems to cause trauma at many levels. Both the positives and the negatives are amplified. Rice uses straw-man imagery. He points to generic weaknesses. We see the us' $n$ ' them scenario played out once again.

Nevertheless, Rice's statement remains intriguing for two reasons. First, we are led to infer that the creation of a new program automatically implies the neglect of an existing program. Second, we are led to infer that administrators are the primary change agents in the academic community. I arrived at this second inference by recasting Rice's logic in terms of the faculty. That is, faculty look to the health of existing programs but do not like to divert money to create new ones.

Personally I have problems with both inferences. Neither is valid. For example, a new program may impact an existing program, but an automatic inference of neglect is unwarranted.

Recently, college-level remedial English programs have come under fire because they divert funds from a posited "real" purpose of the university. Some, including both faculty and administrators, also argue that the teaching of remedial English by universities relieves the $\mathrm{K}-12$ system from its basic responsibility to prepare graduates who can read and write. Others, including both faculty and administrators, argue that if the K-12 system cannot do the job, the university must pick up the slack so its graduates can read and write.

This is a complicated issue. If we cast labels on others we will do little to promote understanding or progress. Common stereotypes only make it easier for some to turn away and to reject responsibility. Individuals who become involved may be scolded because narrow self-interests are impacted. This pattern of behavior is played out daily.

Indeed, the key to the debate on many issues probably centers on the personal interests of the participants. For the instructional faculty, it is often a matter of the number and kind of courses that they teach. Learning and the acquisition of knowledge may at times take second place to bread-and-butter issues.

This is not new. If I were to search for a place to locate a generic weakness, it would be between our interest toward self and our interest toward others. Certainly, administrators 
may be more inclined to support a change in an educational program than a change in an administrative program. The location of the impact and its remoteness from self will often influence one's receptivity toward change.

If we use life and death symbols to flavor the debate on new programs and existing programs, we obscure enlightenment. Our own self-interests need to be examined with greater candor. As a corollary, all parties need to be sensitive to personal factors if we are to make significant progress in resolving complex issues.

Movement toward new programs can be both beneficial and threatening. Clear reasoning will help us to avoid the dilemma of the old horse-lover, who, when confronted with the horseless carriage in the early 1900 s, exclaimed, "If only we provided a good nutritional diet for our horses, then they would be just as fast."

We need to place our bets more wisely.

CHARLES MARTELL

\section{IN FORTHCOMING ISSUES OF \\ COLLEGE \& RESEARCH LIBRARIES}

Selected Papers from the ACRL Fourth National Conference, Baltimore, April 9-12, 1986

Coping with Information Load: User Strategies and Implications for Librarians by Joel Rudd and Mary Jo Rudd

Performance Appraisal: Is It Working?

By Charles A. Schwartz

The Managerial Roles of Academic Library Directors

By Michael Ann Moskowitz

The Effect of Service Awareness on Survey Response

by Ruth A. Pagell and Edward J. Lusk

Book Availability at the University of California, Santa Cruz

by Terry Ellen Ferl and Margaret G. Robinson

LC Staff Test Optical Disk System

by Victoria Ann Reich and Melissa Ann Betcher 


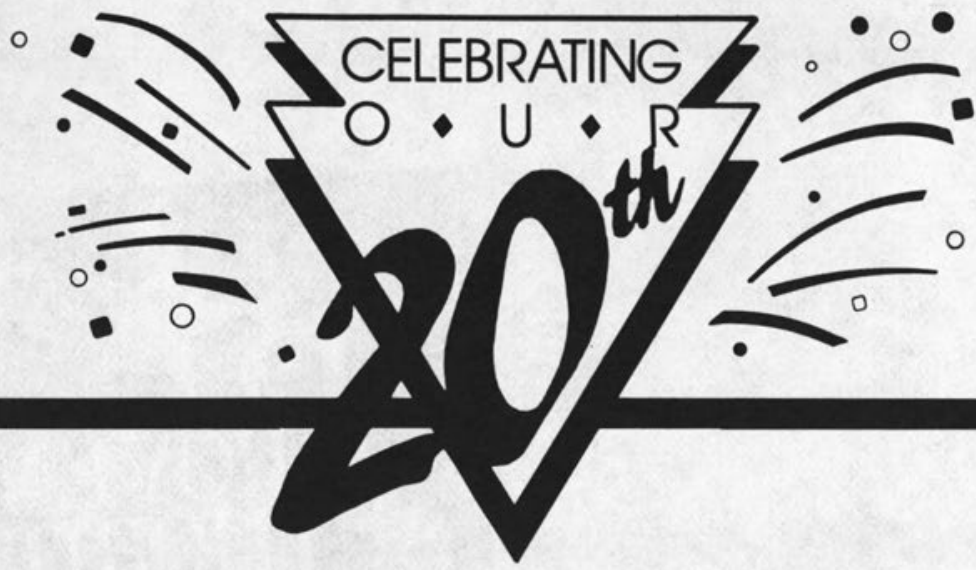

Twenty years ago, Research Publications began as a small academic microform publisher of manuscripts and rare books.

\section{Today, Research}

Publications is an international source of information products and services for academic, public, government, and corporate libraries. We provide:

- Collections

- Newspapers and Periodicals
- Patents

- Reference Books

For twenty years, Research Publications has strived to bring our customers the services you have requested and the quality you have demanded. Thank you for your continued support. We at Research Publications look forward to working with you to make our next twenty years the most rewarding yet.
Research Publications 12 Lunar Drive/Drawer AB Woodbridge, СТ 06525 (203) $397-2600$ Toll-free: 1-800-REACH-RP TWX: 710-465-6345 FAX: 203-397-3893
Outside North and South America:

P.O. Box 45

Reading, RGI $8 \mathrm{HF}$, England

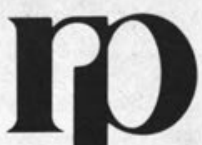

TEL: 0734-583247

TELEX: 848336NADL G

FAX: 011-44-734-591325 
E xperience counts in authority control. And if your library is choosing a vendor to apply authority control to your MARC records before you put them online, consider the following:

Blackwell North America has 12 years experience performing retrospective automated authority control edits.

B/NA has performed subject authority control on hundreds of MARC databases since LC began issuing machine readable subject authority data in 1973; and name authority control on over 150 MARC databases since LC began issuing machine readable name authority data in 1982. In addition, B/NA was first to offer library specific authority files for loading into online systems. B/NA's staff of authority control editors has combined experience of over 33 years, and applies manual corrections to your bibliographic records where the automated system stops.

$\mathrm{B} / \mathrm{NA}$ is interested in your project, and will deliver professional service on schedule.

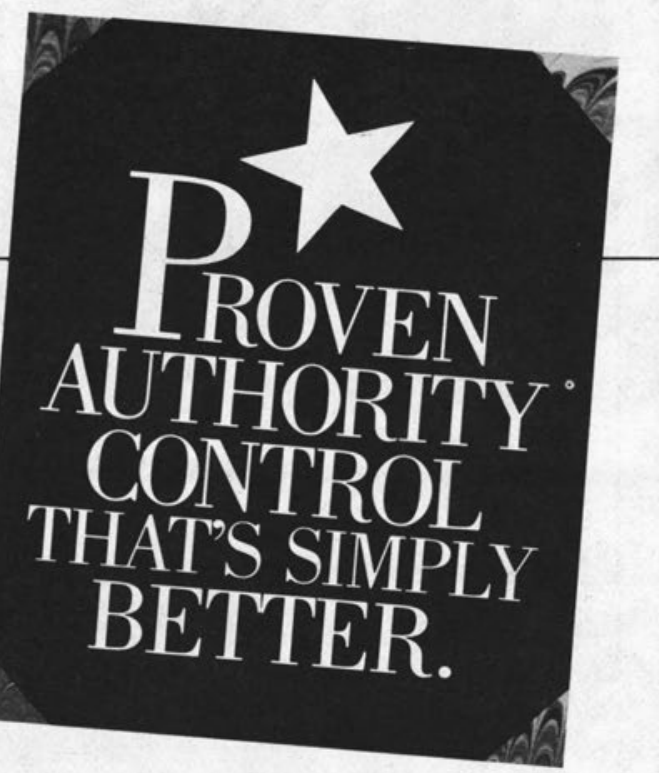

$\star$ B/NA AUTHORITY CONTROL CUSTOMERS

University of Illinois at Chicago

University of Wisconsin, Eau Claire

Grove City Public Library

Vanderbilt University

University of Notre Dame

Ball State University

College of William \& Mary

University of Texas, El Paso

Warren Trumbull County Public Library

University of Oregon

Lamar University

University of Delaware

Rollins College

Louisiana State University

Johns Hopkins University

For more information on authority control for your library, contact B/NA's authorities on authority control at the address below.

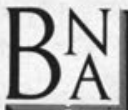

BLACKWELL NORTH AMERICA, INC. 6024 S.W. Jean Road, Building G

Lake Oswego, OR 97034

Phone toll-free 800-547-6426

c Blackwell North America, 1985 